\author{
키토산이 저아질산나트륨 소시지의 유산나트륨 저감화에 미치는 영향 \\ 강종옥* · 이상길 \\ 단국대학교 동물자원학과
}

\title{
Effects of Chitosan on Reduction of Sodium Lactate in Sodium Nitrite-reduced Sausages
}

\author{
Jong Ok Kang* and Sang Gil Lee \\ Department of Animal Resources and Science, Dankook University
}

\begin{abstract}
The study was carried out to investigate the effects of chitosan-adding (0.5-1.5\%) on nitrite-reduced (30 ppm) and sodium lactate-reduced $(0-2 \%)$ sausages to avoid using excessively sodium lacte, which is substituted for sodium nitrite, The number of 24 rats for blood properties were used in this experiment and raised for 1-4 weeks. The color of sausages showed significant differences each treatment $(\mathrm{p}<0.05)$ and $\mathrm{a}^{*}$ (redness) had the highest value in control (nitrite $\left.100 \mathrm{ppm}\right)$ and $\mathrm{b}^{*}$ (yellowness) had the lowest value in $\mathrm{T} 3$ (nitrite $30 \mathrm{ppm}+$ sodium lactate $0 \%+$ chitosan $1.5 \%$ ). There were not significant differences in $\mathrm{pH}$ (5.53-5.66) and water holding capacity (66.06-69.75\%) between control and two treatments (T1, nitrite 30 ppm + sodium lactate $2 \%+$ chitosan $0.5 \%$; T2, nitrite $30 \mathrm{ppm}+$ sodium lactate $1 \%+$ chitosan $1 \%$ ), but $\mathrm{T} 3$ had significant differences in $\mathrm{pH}(5.06)$ and water holding capacity $(62.44 \%)$, respectively. Springiness, cohesiveness, chewness and adhesiveness in texture analysis had not significant differences between control and three treatments, but hardness and gumminess had lower values in control than in three treatments. Appearance and color in sensory evaluation had higher values in control than in T1, but texture and flavor had lower values than in three treatments. Microbial counts had not significant differences in control, T2 and T3 for 1 week, for 3 weeks, it showed the lowest value in control than in three treatments. Anti-oxidant activity (TBARS) in sausages were more effective in control $(\mathrm{p}<0.05)$. The body weigh gain of rat were significantly increased in three treatments and also neutral fat, total cholesterol, LDL-cholesterol were significantly decreased in three treatments. However, T1 treatment had higher blood glucose content and significantly decreased in HDL-cholesterol, compared with control, but T2 and T3 treatments showed similar results in body weight gain and blood properties. So, through the addition of chitosan, it's possible to manufacture nitrite-reduced and sodium lactate-reduced sausage which is supplemented its function.
\end{abstract}

(Key words : Chitosan, Sodium lactate, Nitrite-reduced sausage, Blood properties)

\section{서 론}

육제품에 첨가되는 아질산염 $\left(\mathrm{NaNO}_{2}\right.$ 또는 $\left.\mathrm{KNO}_{2}\right)$ 의 주요 기능 은 발색, 항미생물, 항산화 및 풍미이며, 이 중에서도 가장 중요하 게 생각되는 것은 제품의 상표에 명시되고 있는 것처럼 발색제로서 의 기능이라 할 수 있다. 발색은 아질산염이 육색소인 마이오글로 빈과 반응하여 가열, 훈연에 의해 NO-hemochromogen으로 환원 되어 아름다운 선홍색을 띠게 된다. 한편 $\mathrm{NO}$ 의 긍정적인 면으로 생체 내에서 효소에 의해 생 합성된 $\mathrm{NO}$ 는 신경계 신경전달물질로 서 뇌세포의 활성화, 혈압조절 및 면역체계에서 암세포의 DNA 증 식을 억제하는 것으로 알려져 있다 (Campbell과 Farrell, 2003).

반면, 아질산염의 섭취는 체내에서 $\mathrm{HNO}_{2}$ 로 변하게 되면 2급 아
민과의 반응으로 nitrosoamine이라는 발암성 물질이 생성될 수가 있다. 따라서 육제품에는 발색에 참여하지 못한 잔류 아질산염이 문제가 된다. 따라서 규제는 완제품에서의 잔존량으로 표시되고 있 는데, 허용량은 제품에 따라 다르다. USDA regulation에 의하면 미국은 40 120 ppm, 유아용은 $0 \mathrm{ppm}$ 이다(Pearson과 Gillett, 1996). 한국과 일본은 $70 \mathrm{ppm}, \mathrm{CODEX}$ 기준은 $120 \mathrm{ppm}$ 이다 (김과 최, 2007; CODEX Alimentarius Commission, 2007).

실제로 육제품에 사용되는 아질산염은 $150 \mathrm{ppm}$ 첨가하여도 완 제품의 최종농도는 $70 \mathrm{ppm}, 75 \mathrm{ppm}$ 첨가 시는 $25 \mathrm{ppm}$ 정도로 즉, $1 / 2$ 이하로 감소되고 있다 (강과 이, 2003). 또한 그 감소량은 $\mathrm{pH}$ 및 저장시간과 온도에 따라 다르다(김과 최, 2007; 김 등, 2000). 또한 식물성 폴리페놀 성분이나 키토산이 첨가되면 아질산

\footnotetext{
* Corresponding author: Jong Ok Kang, Department of Animal Resources and Science, Dankook University, Chenan, 330-714, Korea.
} Tel: 82-41-550-3653, Fax: 82-41-550-3653, E-mail: jokang@dankook.ac.kr 
염 소거작용으로 아질산염은 더욱 감소된다(최 등, 2003; 양 등, 2006).

잔류 아질산염은 Clostridium botulinum 식중독균 및 미생물의 성장을 억제한다는 점에서 허용되고 있다. 그러나 허용량 범위내 아질산염의 섭취는 실제로는 양적으로 소량일 뿐만 아니라, 비타민 $\mathrm{C}$ 및 $\mathrm{E}$ 등의 항산화물질 첨가로 발암물질이 생성가능성은 거의 없다.

그럼에도 불구하고, 친환경 웰빙의 축산식품을 지향한다는 관점 에서 아질산염을 천연물로 대체하고자 하는 연구가 발색 및 항 미 생물을 중심으로 진행되어 왔다(류 등, 2003; O’Boyle 등, 1990). 특히 유산염은 발효미생물에 의해 생산되고 있어 아질산염의 화학 성에 대해 천연성분으로써, 아질산염의 대체수단으로 그 사용가능 성이 제기되었다(진 등, 2006). 그러나, 유산나트륨의 단독 사용은 항미생물 작용은 있으나, 발색효과를 주지 못하는 단점이 있다(강 과 이, 2008).

한편 키토산(chitosan)은 홍게 (red crap)의 부산물인 껍질에서 추출된 동물성 식이섬유로 유산염과 마찬가지로 아질산염을 대체할 수 있을 것으로 보고되고 있다. 키토산은 유산염과 달리 육제품에 첨가되었을 때 항산화, 항종양 (Choi와 Chin, 2009) 및 수용성 색 소와의 결합능으로부터 발색효과가 있는 것으로 생각되고 있다(윤 등, 2001). 그러나 그 효과는 아질산염 처리구에 비해 매우 미흡 하다. 따라서 키토산도 유산염과 마찬가지로 발색작용보다는 항미 생물 기능으로 잘 알려져 있다(윤 등, 2001: Choi와 Chin, 2009). 특히 키토산은 보습효과 및 제품의 연도(tenderness)에도 탁월한 기능을 발휘하는 것으로도 알려져 있다 (강과 이, 2003).

그러나 아질산염 첨가 없이 유산나트륨이나 키토산만을 첨가할 경우 항미생물의 작용으로는 1.5 3.5\%는 사용되어야 하므로 (Mass 등, 1989: 최 등, 2003) 그 농도가 일반 첨가물에 비해 너무 높다 고 할 수 있다.

이에 이의 양자의 보완책으로 소량의 유산나트륨 (1 2\%)과 소량 의 아질산나트륨 $(30 \mathrm{ppm})$ 을 첨가하여도 발색 및 보존성에서 100 $\mathrm{ppm}$ 의 아질산염을 첨가한 통상의 제품과 별 차이가 없었다. 또한 폴리페놀 성분인 선인장색소와 유산나트륨을 혼합 첨가한 저농도의 아질산나트륨 소시지는 발색, 보존성, 보수력 및 맛에 있어서도 양 호한 결과를 보였을 뿐만 아니라, 실험동물의 경우 콜레스테롤과 중성지방은 오히려 감소하였다 (강과 이, 2008).

따라서 본 연구에서는 유산나트륨의 단독 사용 함량 $(1.5 \sim 3.5 \%)$ 을 더욱 줄이기 위하여 키토산을 혼합 사용함으로서 유산나트륨의 저감화를 목적으로 하였다. 이에 NO- hemocromogen의 형성 및 발색에 필요하다고 생각되는 정도의 저농도의 아질산나트륨 $(30$ $\mathrm{ppm})$ 을 첨가하여 제품의 발색, 항미생물 등의 이화학적 성상과 실험동물의 중성지방, 콜레스테롤 등의 혈액성상에 대하여 검토 하였다.

\section{재료 및 방법}

\section{1. 소시지 제조 및 배합}

원료육은 대전충남양돈협동 조합에서 냉장 돈육의 후지(뒷다리) 및 등 지방을 구매하였으며, 사용 시까지 돈육은 냉장상태로, 지방 은 냉동상태로 보관 되었다. 유산나트륨은 (주)송광 양행, 키토산은 이지생명과학(주)로부터 각각 구입되었다. 아질산나트륨은 $5 \%$ 의 아질산나트륨을 함유한 nitrite pickle salt (NPS)가 사용되었다. 소 시지는 강과 이(2008)의 방법을 참고하여 케이싱은 셀룰로스 직경 $3 \mathrm{~cm}$, 훈연은 $50^{\circ} \mathrm{C}$ 에서 20 분, 가열은 내부온도가 $63^{\circ} \mathrm{C}$ 에서 30 분 이 되도록 외부온도를 $72^{\circ} \mathrm{C}$ 로 하였다. 제조 시 $\mathrm{NPS} 0.2 \%$ (아질산 나트륨 $100 \mathrm{ppm}$ )만을 첨가한 것을 대조구 $(\mathrm{C})$ 로 하였으며, 각 처 리구는 $0.06 \%$ (아질산나트륨 $30 \mathrm{ppm}$ )로 아질산나트륨을 감소시킨 반면, 저장성을 위한 키토산 $(\mathrm{MW}: 130 \mathrm{kDa})$ 과 유산나트륨의 혼합 비율은 $0.5: 2 \%(\mathrm{~T} 1), 1: 1 \%(\mathrm{~T} 2), 1.5: 0 \%$ (T3)로 하였다.

그 외 첨가제로는 인산염 0.25 , 비타민 C 0.05 , Mace 0.05 , Coriander 0.05 , White pepper 0.2 , MSG (monosodium glutamate) 0.2 , Ginger 0.03, Cardamom 0.02, 설탕 $0.5 \%$, 선인장 색소 0.2 $\%$ 가 첨가되었다.

\section{2. 실험동물 사육 및 혈액 채취}

생후 5주 (평균체중 125 150g)된 Sprague-Dawley (SD)계 수컷 흰쥐 24마리를 코아텍(Korea)에서 구입하여 실험시작 전 1주일간 적응시킨 후 체중이 $170 \mathrm{~g}$ 내외인 쥐들을 체중에 따라 난괴법 (randomized complete block design)에 의해 6마리씩 4군으로 분 류하여 4주간 사육하였다. 물은 자유급여 하였고, clean rack (신바 이오텍사, Korea)에서 사육하였으며 소시지는 매일 동일한 시간에 $40 \mathrm{~g}$ 으로 제한 급여하였다. 혈액은 꼬리정맥 및 심장에서 채취하였 고 헤파린 처리된 tube에 넣어 ice bath에 20분간 방치한 후 $3,000 \mathrm{rpm}$ 에서 15 분간 원심 분리로 혈장을 분리하였다.

\section{3. 색도측정}

시료를 절단하여 표면을 Chroma Meter (Model CR-200b, Minolta, Japan)로 C광원에서 명도(lightness)를 나타내는 $\mathrm{L}^{*}$, 적 색도 (redness)를 나타내는 $\mathrm{a}^{*}$, 황색도 (yellowness)를 나타내는 $\mathrm{b}^{*}$ 값을 각각 측정하였다. 이때의 표준색판은 calibration plate로 $\mathrm{L}=99.6, \mathrm{a}=0.3, \mathrm{~b}=1.7$ 이었다. 시료는 6 부위, 7 반복 측정하여 평 균값을 구하였다.

\section{4. $\mathrm{pH}$ 측정 및 보수력 측정}

소시지의 $\mathrm{pH}$ 값은 $\mathrm{pH}$ meter(HANNA instruments, $\mathrm{HI}$ 8424) 를 사용하여 소시지 표면에 임의로 5 부분을 측정하여 평균치를 구 
하였다. 보수력 측정은 가압여과지 면적법으로 시료 $2 \mathrm{~g}$ 을 여과지 (Whatman No. 2)에 놓고 $10 \mathrm{~kg} / \mathrm{cm}^{2}$ 의 압력으로 1 분간 가압 후, 여과지에 퍼진 수분의 면적을 planimeter로 측정하였다.

계산식은 보수력 $(\%)=(\mathrm{A}-\mathrm{B}) / \times 100$ 으로 하였으며, 이 때 $\mathrm{A}$ 는 여과지 전체면적, $\mathrm{B}$ 는 소시지에 의하여 생성된 수분의 면적을 나 타낸다.

\section{5. 산패도 측정}

소시지의 지방산패 정도를 평가하기 위한 TBARS (Thio-

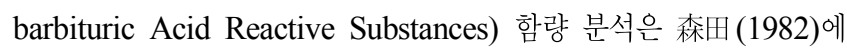
의해 소개된 방법으로 돈육 $5 \mathrm{~g}$ 을 homogenizer에 $20 \%$ trichloroacetic acid (TCA)용액 $5 \mathrm{~mL}, \mathrm{~N} / 100$ thiobarbituric acid (TBA) $10 \mathrm{~mL}$ 를 첨가하여 $100^{\circ} \mathrm{C}$ 에서 30 분간 가열하였다. 냉각한 후 $3,000 \mathrm{rpm}$ 에서 10 분간 원심분리하고 상등액에 isoamyl alcohol 과 pyrimidine $2: 1$ 용액을 $15 \mathrm{~mL}$ 첨가하여 진탕 교반하였다. 2분 후 $3,000 \mathrm{rpm}$ 에서 10 분간 원심분리, 상등액을 No. 1 filter paper 로 여과하였다. 여과액의 흡광도는 $538 \mathrm{~nm}$ 에서 측정하였으며, 흡 광도가 클수록 시료 중 지방의 산화가 진행된 것으로 하였다.

\section{6. 조직검사 및 관능검사}

조직검사를 위해 냉장보관중인 실험용 소시지를 실온에서 30 분 정도 방치한 후 직경 $3 \mathrm{~cm}$, 높이 약 $1.3 \mathrm{~cm}$ 로 균일하게 자른 후 texture analyser(TAXT-2/25, Stable Micro Systems, Surrey, England)의 $500 \mathrm{~N}$ load cell을 이용하여 2번 물림으로 원래 높이 의 약 $75 \%$ 정도 가압하고, $500 \mathrm{~mm} / \mathrm{min}$ 의 cross-head speed와 $100 \mathrm{~mm} / \mathrm{min}$ 의 chart speed로 조직감의 일차적인 특징인 탄력성 (Springiness), 응집성(Cohesiveness), 경도(Hardness)와 씹힙성 (Chewiness), 검성(Gumminess), 부착성 (Adhesiveness) 등을 시 료 당 10 회 반복 측정하여 그 평균값을 구하였다. 관능검사는 훈련 된 관능검사 요원 15 명을 선발하여 실시하였으며 외관, 색, 조직 및 향미에 대하여 각각 5점 척도법을 이용해 평가하였다. 평가방법 은 $5=$ 매우 우수, $4=$ 우수, $3=$ 보통, $2=$ 불량, $1=$ 불만족, $0=$ 평 가 불가능으로 하였다. 평가 시 칸막이 및 주위환경을 어둡게 하여 조용한 분위기에서, 맛을 본 뒤는 정수된 물로 입을 헹구게 하였다.

\section{7. 총 세균수 측정}

$3{ }^{\circ} \mathrm{C}$ 에서 냉장 보관된 각 시료는 $10 \mathrm{~g}$ 을 취해 멸균한 생리식염수 $90 \mathrm{ml}$ 와 함께 stomacher (stomacher 400 Lab Blend, SEWARD, England)를 이용하여 2분간 혼합하고 10 진 희석법으로 희석하여 각각을 Petrifilm ${ }^{\mathrm{TM}}$ (3M Micro- biology Products)에 접종하고 3 $7^{\circ} \mathrm{C}$ 에서 24 48h 배양한 후 균수를 측정하였다.

\section{8. 증체량 및 혈액성상}

증체량은 1 주일 간격으로 측정 전 2 시간 절식 후 체중을 측정하 였으며, 혈당측정은 급여 28 일째에 실험동물을 12 시간 절식시킨 후 꼬리 정맥에서 채혈하여 공복 시 혈당수준을 측정한 후, 다시 sausage를 급여하고 120 분 뒤에 꼬리 정맥으로부터 채혈하여 혈당 계 (Onetouch Ultra ${ }^{\mathrm{TM}}$, Lifescan, Korea)로 측정하였다. 중성지방 을 비롯한 HDL (high density lipo-protein)-콜레스테롤 및 LDL (low density lipo-protein)-콜레스테롤은 녹십자에 분석의뢰 하 였다.

\section{9. 통계처리}

모든 자료는 SAS (1999)의 GLM(General Linear Model) procedure를 통하여 분석하였고, duncan's 다중검정법을 이용하여 $0.5 \%$ 수준에서 처리구간의 유의성을 검정하였다.

\section{결과 및 고찰}

\section{1. 색도}

Table 1에서 보는 바와 같이 L*값(명도)은 아질산나트륨 100 $\mathrm{ppm}$ 의 대조구가 $30 \mathrm{ppm}$ 처리구 (T1, T2, T3) 보다 높게 나타났 다. 일반적으로 아질산나트륨 함량이 낮거나, 유산나트륨과 키토산 의 첨가는 낮은 $\mathrm{L}^{*}$ 값을 나타내는 것으로 보인다(강과 이, 2008; 윤 등, 2001). $\mathrm{a}^{*}$ 값(적색도)은 대조구가 처리구보다 높게 나타났으 나, 처리구에서는 유산나트륨 첨가량이 많은 $\mathrm{T} 1$ 이 유산나트륨과 동량의 키토산 첨가구 $(\mathrm{T} 2)$ 및 키토산 첨가량 $(1.5 \%)$ 이 많은 첨가 구(T3) 보다 높은 수치를 보였다. 강과 이 (2008)에 의하면 $2 \%$ 유 산나트륨 첨가구에서 $100 \mathrm{ppm}$ 첨가의 대조구와 비슷한 $\mathrm{a}^{*}$ 값을 나 타냈다고 하였으나 본 실험에서는 $0.5 \%$ 의 키토산 혼용에 의해 $\mathrm{a}^{*}$ 값이 떨어진 것으로 생각된다. $\mathrm{b}^{*}$ 값(황색도)은 유산나트륨 보다 키 토산의 함량이 많은 $\mathrm{T} 3$ 가 최고치를 나타내었다 $(\mathrm{p}<0.05 \%)$. $\mathrm{a}^{*}$ 값 과 $\mathrm{L}^{*}$ 값에 관하여 윤 등 (2001)에 의하면 키토산 $0.2 \sim 0.35 \%$ 에서 는 $\mathrm{a}^{*}$ 값이 향상되는 반면 $0.5 \%$ 첨가에서는 $\mathrm{a}^{*}$ 값이 저하되고, $\mathrm{b}^{*}$ 값은 높은 것으로 나타났다. 따라서 첨가량에 따라 유산나트륨은 $a^{*}$ 값을 높이고 유산나트륨에 비해 키토산은 $b^{*}$ 값을 높이는 것으 로 사료되었다. 또한 $\mathrm{b}^{*}$ 값에 관해서는 선인장, 레드비트 등의 천연 색소의 첨가도 $\mathrm{b}^{*}$ 값을 높이며, 베타 케로틴 함량이 많은 우육에서 도 이와 같은 결과를 보였다(Yang, 1999). 한편 유산나트륨과 키 토산 1:1의 $\mathrm{T} 2$ 는 $\mathrm{T} 1, \mathrm{~T} 3$ 의 중간 형태를 보였다.

\section{2. $\mathrm{pH}$ 와 보수력}

Table 2에 의하면 $\mathrm{pH}$ 와 보수력 (water holding capacity)은 $\mathrm{T} 3$ 가 유의적으로 낮았고 $(\mathrm{p}<0.05), \mathrm{T} 1, \mathrm{~T} 2$ 가 유의성은 없으나 대조구 에 비해 조금 높게 나타났다 $(\mathrm{p}>0.05)$. 일반적으로 $\mathrm{pH}$ 와 보수력은 밀접하게 관련돼 있다(Judge 등, 1975). 즉 알칼리 $\mathrm{pH}$ 에서 높은 
Table 1. Effects of chitosan and sodium lactate on color of nitrite-reduced sausages

\begin{tabular}{cccccc}
\hline \multirow{2}{*}{ Parameters } & \multicolumn{5}{c}{ Treatments } \\
\cline { 2 - 6 } & $\mathrm{C}^{1)}$ & $\mathrm{T}^{2)}$ & $\mathrm{T} 2^{3)}$ & $\mathrm{T}^{4)}$ & $\mathrm{SEM}^{5)}$ \\
\hline \hline $\mathrm{L}^{* 6)}$ & $73.33^{\mathrm{a}}$ & $71.37^{\mathrm{c}}$ & $71.61^{\mathrm{c}}$ & $72.05^{\mathrm{b}}$ & 0.10 \\
$\mathrm{a}^{* 7)}$ & $9.91^{\mathrm{a}}$ & $9.34^{\mathrm{b}}$ & $8.75^{\mathrm{c}}$ & $8.03^{\mathrm{d}}$ & 0.09 \\
$\mathrm{~b}^{* 8)}$ & $5.51^{\mathrm{d}}$ & $11.58^{\mathrm{c}}$ & $12.65^{\mathrm{b}}$ & $13.33^{\mathrm{a}}$ & 0.08 \\
\hline
\end{tabular}

\footnotetext{
1) Control (Sodium nitrite $100 \mathrm{ppm}$ )

2) Treatment 1 (sodium nitrite $30 \mathrm{ppm}+$ chitosan $0.5 \%+$ sodium lactate $2 \%$ )

3) Treatment 2 (sodium nitrite $30 \mathrm{ppm}+$ chitosan $1 \%+$ sodium lactate $1 \%$ )

4) Treatment 3 (sodium nitrite $30 \mathrm{ppm}+$ chitosan $1.5 \%$ + sodium lactate $0 \%$ )

5) Pooled standard error of mean.

6) Lightness; ${ }^{7)}$ Redness; ${ }^{8)}$ Yellowness.

${ }^{a-d}$ Means with same row having same superscript are not significantly different $(\mathrm{p}<0.05)$.
}

보수력, 산성 $\mathrm{pH}$ 에서 낮은 보수력을 보인다. 소시지에 인산염을 첨 가하는 이유도 $\mathrm{pH}$ 를 높여 보수력을 향상시키는데 있다. $\mathrm{T} 3$ 는 대조 구 및 다른 처리구에 비해 키토산 $(130 \mathrm{kDa})$ 첨가량이 많아 $\mathrm{pH}$ 를 유의적으로 낮추면서 보수력도 저하된 것으로 보인다(Table 2). 윤 등 (2004)에 의하면 고분자량 키토산의 첨가량이 많을수록 $\mathrm{pH}$ 는 감소한다고 하였으며, Choi와 Chin (2009)은 고분자량의 키토 산은 저분자량의 키토산에 비해 $\mathrm{pH}$ 가 감소함을 보여주었다.

한편 유산나트륨은 $\mathrm{pH}$ 가 높아져도 보수력이 향상되지 않는 반면 키토산은 $\mathrm{pH}$ 의 변화에 따라 보수력에 영향을 미치면서도 유산나트 륨에 비해 낮은 $\mathrm{pH}$ 에서도 보수력이 유지되는 것으로 나타났다(강 과 이, 2003; 강과 이, 2008). 이는 키토산이 동물성 식이섬유로서 의 수화기능으로 생각된다.

\section{3. 산패도}

Fig. 1은 지방산화도를 TBARS로 나타낸 것이다. 보는 바와 같 이 지방산화도는 대조구에서 $\mathrm{T} 1, \mathrm{~T} 2, \mathrm{~T} 3$ 순으로 유의적으로 증가 하고 있다. 강과 이 (2008)에 의하면 유산나트륨 단독 첨가구에 비 해 오히려 아질산나트륨 및 소량의 아질산나트륨 첨가구가 훨씬 더 낮은 산화도를 보여, 소량일지라도 아질산나트륨이 항산화 효과가 있음을 보고하였다. 반편 윤 등 (2004)은 키토산 함량이 증가할수 록 항산화 효과가 있음을 보고하였다. 그러나 본 실험결과로부터 아질산나트륨과 유산나트륨이 있는 경우 항산화에 관한한 아질산나

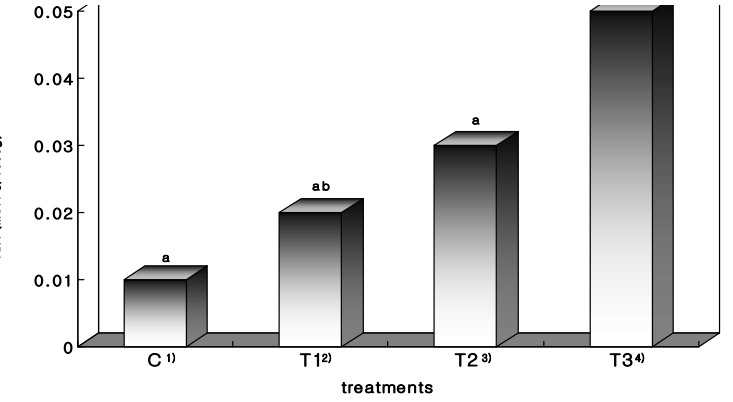

Fig. 1. Effect of chitosan and sodium lactate on TBARS of nitrite-reduced sausages.

1)-4) Abbreviation of is the same as Table 1.

${ }^{\text {a-d }}$ Means with same row having same superscript are not significantly different $(\mathrm{p}<0.05)$.

트륨 및 소량의 아질산나트륨> 유산나트륨> 키토산의 순으로 분석 되었다.

\section{4. 조직 및 관능검사}

Table 3은 조직 (물성)검사를 나타낸 것으로 조직의 탄력성 (springiness), 응집성 (cohesiveness), 씹힘성 (chewiness) 및 부착

Table 2. Effect of chitosan and sodium lactate on $\mathrm{pH}, \mathrm{WHC}$ of nitrite-reduced sausage

\begin{tabular}{crrrrr}
\hline \multirow{2}{*}{ Parameters } & \multicolumn{5}{c}{ Treatments } \\
\cline { 2 - 6 } & \multicolumn{1}{c}{$\mathrm{C}^{1)}$} & \multicolumn{1}{c}{$1^{2)}$} & \multicolumn{1}{c}{$2^{3)}$} & $\mathrm{SEM}^{5)}$ \\
\hline \hline $\mathrm{pH}$ & $5.53^{\mathrm{a}}$ & $5.63^{\mathrm{a}}$ & $5.66^{\mathrm{a}}$ & $5.06^{\mathrm{b}}$ & 0.06 \\
$\mathrm{WHC}(\%)^{6}$ & $66.06^{\mathrm{a}}$ & $69.75^{\mathrm{a}}$ & $67.92^{\mathrm{a}}$ & $62.44^{\mathrm{b}}$ & 1.16 \\
\hline
\end{tabular}

\footnotetext{
1)-4) Abbreviation is the same as Table 1.

5) Pooled standard error of mean.

6) WHC: Water holding capacity.

${ }^{a-b}$ Means with same row having same superscript are not significantly different $(p<0.05)$.
} 
Table 3. Effect of chitosan and sodium lactate on texture analysis of nitrite-reduced sausages

\begin{tabular}{lrrrrr}
\hline Parameters & \multicolumn{3}{c}{ Treatments } & $\mathrm{T}^{4)}$ & $\mathrm{SEM}^{5)}$ \\
\cline { 2 - 6 } Springiness & $\mathrm{C}^{1)}$ & $\mathrm{T}^{2)}$ & $0.91^{\mathrm{a}}$ & $0.90^{\mathrm{a}}$ & 0.02 \\
Cohesiveness & $0.96^{\mathrm{a}}$ & $0.94^{\mathrm{a}}$ & $0.60^{\mathrm{a}}$ & $0.60^{\mathrm{a}}$ & 0.01 \\
Chewness (g) & $0.59^{\mathrm{a}}$ & $0.60^{\mathrm{a}}$ & $911.09^{\mathrm{a}}$ & $836.08^{\mathrm{a}}$ & 60.12 \\
Hardness (g) & $736.96^{\mathrm{a}}$ & $848.40^{\mathrm{a}}$ & $1675.70^{\mathrm{a}}$ & $1518.00^{\mathrm{ab}}$ & 88.01 \\
Gumminess (g) & $1303.90^{\mathrm{b}}$ & $1526.50^{\mathrm{ab}}$ & $998.86^{\mathrm{a}}$ & $913.03^{\mathrm{ab}}$ & 51.98 \\
Adhesiveness (g) & $769.50^{\mathrm{b}}$ & $908.06^{\mathrm{ab}}$ & $-23.74^{\mathrm{a}}$ & $-27.53^{\mathrm{a}}$ & 4.50 \\
\hline
\end{tabular}

1)-4) Abbreviation is the same as Table 1.

${ }^{5)}$ Pooled standard error of mean..

${ }^{a-b}$ Means with same row having same superscript are not significantly different $(\mathrm{p}<0.05)$.

성 (adhesiveness)에서는 대조구와 각 처리구간에 유의적인 차이를 발견할 수 없었다 $(\mathrm{p}>0.05)$. 그러나 경도(hardness)와 검성 (gumminess) 에서 대조구 보다 처리구가 약간 높게 나타났다. 강과 이 (2008)는 유산나트륨 첨가는 경도와 검성을 약간 높인다고 보고하였으며, 진 과 최(2001)도 유산나트륨의 함량이 증가함에 따라 부서짐성, 경 도, 저작성과 검성이 높아지고, 키토산 첨가시 저분자량의 키토산 보다 고분자량의 키토산에 의해서도 높아진 결과를 보여주었다 (Choi와 Chin, 2009). 그러나 T2가 T3 보다 경도와 검성이 더 높 은 요인에 대해서는 유산나트륨의 보수력 저하성과 고분자량 키토 산의 섬유성의 복합작용으로 생각되나 그 상세에 대해선 아직 불분 명하다.

Table 4에서 보는 바와 같이 관능검사에 의한 외관 및 색상은 대조구가 좋은 평점을 받았으나, 조직감 및 풍미에서는 처리구에서 각각 좋은 평점을 받았다. 그러나 처리구간에 유의적인 차이는 없 었다 $(\mathrm{p}<0.05)$. 이는 저 아질산나트륨에 유산나트륨만 첨가한 소시 지에서 나타난 결과와도 일치한다 (강과 이, 2008). 따라서 저 아질 산나트륨, 저 유산나트륨과 키토산의 혼용첨가도 조직감과 풍미면 에서 문제가 되지 않음을 시사하고 있다고 판단된다.

5. 총세균수
총세균수(Table 5)는 냉장저장 1주에서는 $\mathrm{T} 1, \mathrm{~T} 2$ 가 대조구 및 $\mathrm{T} 3$ 보다 조금 많게 나타났으며, 대조구와 $\mathrm{T} 3$ 간에는 유의적인 차이 가 없었다. 저장 3 주에서는 대조구와 처리구 사이에는 유의적인 차 이를 보였으나 처리구 사이에는 유의저인 차이를 보이지 않았다 $(\mathrm{p}>0.05)$. 그러나 저장 5 주에서는 처리구가 대조구 보다 유의적으 로 항 미생물 효과를 보여주었다(data not shown). 이와 유사한 결과로 Choi와 Chin (2009)도 유산나트륨 단독 첨가가 더욱 강력 한 항미생물 효과가 있으나, 유산나트륨과 키토산의 혼합첨가는 아 질산나트륨 $150 \mathrm{ppm}$ 첨가에 비해 L. monocytogenes 및 E. coli O157: H7의 성장을 억제할 수 있었다고 보고하였다. 뿐만 아니라 유산나트륨은 Cl. botulinum의 성장도 억제한다 (Mass 등, 1989). 한편 키토산도 저지방 소시지의 보존성을 증가시키는 항미생물 효 과가 있는데 (Sagoo 등, 2002), 키토산은 그 분자량과 아질산나트 륨의 함량에 따라 $0.2 \sim 0.35 \%$ 첨가로 대부분의 미생물은 $70 \%$ 이 상 성장이 억제되며, 키토산 첨가량이 $0.1,0.5,1 \%$ 로 증가함에 따 라 저장성이 증진되었다고 하였다 (윤 등, 2001; 윤 등, 2004). 이 러한 키토산의 항균작용 메카니즘으로는 양전하를 가진 키토산의 아미노기가 세균세포벽의 음전하와 이온결합을 형성하기 때문으로 추정하고 있다(전 등, 1996).

Table 4. Effect of chitosan and sodium lactate on sensory evaluation of nitrite-reduced sausages

\begin{tabular}{lccccc}
\hline \multirow{2}{*}{ Parameters } & \multicolumn{5}{c}{ Treatments } \\
\cline { 2 - 6 } & $\mathrm{C}^{\mathrm{l})}$ & $\mathrm{T}^{2)}$ & $\mathrm{T}^{3)}$ & $\mathrm{T}^{4)}$ & $\mathrm{SEM}^{5)}$ \\
\hline \hline Appearance & $3.60^{\mathrm{a}}$ & $3.20^{\mathrm{b}}$ & $3.25^{\mathrm{ab}}$ & $3.45^{\mathrm{ab}}$ & 0.12 \\
Color & $3.13^{\mathrm{a}}$ & $2.70^{\mathrm{b}}$ & $2.85^{\mathrm{ab}}$ & $3.00^{\mathrm{ab}}$ & 0.12 \\
Texture & $2.68^{\mathrm{b}}$ & $3.64^{\mathrm{a}}$ & $3.64^{\mathrm{a}}$ & $3.88^{\mathrm{a}}$ & 0.13 \\
Flavor & $2.92^{\mathrm{b}}$ & $3.38^{\mathrm{a}}$ & $3.53^{\mathrm{a}}$ & $3.48^{\mathrm{a}}$ & 0.14 \\
\hline
\end{tabular}

\footnotetext{
1)-4) Abbreviation is the same as Table 1.

${ }^{5)}$ Pooled standard error of mean.

a-b Means with same row having same superscript are not significantly different $(\mathrm{p}<0.05)$.
} 
Table 5. Effect of chitosan and sodium lactate on changes of total plate counts (log CFU/g) of nitrite-reduced sausages during storage at $3^{\circ} \mathrm{C}$

\begin{tabular}{|c|c|c|c|c|}
\hline \multirow{2}{*}{$\log \mathrm{CFU} / \mathrm{g}$} & \multicolumn{4}{|c|}{ Treatment } \\
\hline & $\mathrm{C}^{1)}$ & $\mathrm{T}^{2)}$ & $\mathrm{T} 2^{3)}$ & $\mathrm{T} 3^{4)}$ \\
\hline 1 week & $4.58^{b c} \pm 0.005$ & $4.72^{\mathrm{a}} \pm 0.005$ & $4.62^{\mathrm{ab}} \pm 0.005$ & $4.50^{\mathrm{c}} \pm 0.005$ \\
\hline 3 weeks & $4.94^{b} \pm 0.024$ & $5.36^{\mathrm{a}} \pm 0.024$ & $5.38^{\mathrm{a}} \pm 0.024$ & $5.34^{\mathrm{a}} \pm 0.024$ \\
\hline
\end{tabular}

${ }^{\mathrm{a}-\mathrm{c}}$ Different letters within the same column differ significantly $(\mathrm{p}<0.05)$.

1)-4) Abbreviation is the same as Table 1.

\section{6. 증체량 및 혈액성상}

실험동물 쥐의 증체효과(Table 6)는 대조구와 처리구간에 유의 적인 차이를 보였으나 $(\mathrm{p}<0.05)$, 처리구간에는 유의적인 차이를 보 이지는 않았다. 그러나 유산나트륨만 처리한 경우 (강과 이, 2008) 는 대조구와 처리구간에도 유의적인 차이를 보이지 않았다. 따라서 대조구와 처리구간에 이러한 증체효과는 키토산의 영향으로 생각되 나 키토산의 증량에 따른 효과는 보이지 않았다. 한편 쥐의 혈당 (Table 7)은 대조구에 비해 T2, T3는 중간을 나타냈으나, T1에서 높게 나타났다 $(\mathrm{p}<0.05)$. 그러나 동일 조건에서 유산나트륨만 첨가 한 경우 (강과 이, 2008)와 비교하면 유사한 경향이나, 그 수치는 증가하지 않았다. 따라서 유산나트륨은 혈당을 높일 수 있으나 키 토산은 혈당을 높이지 않는다고 생각된다. 이러한 판단 근거로는 생화학적으로 혈당의 분해는 유산을 생성하고, 유산은 혈당생합성 의 재료가 될 수 있으며, 키토산은 동물성 식이섬유로써 쉽게 분해 되지 않기 때문으로 여겨진다.

또한 키토산의 양이온의 유리아미노기는 체내 지방의 흡수를 억 제하는 것으로 보고 있다(전 등, 1996). Table 8은 총콜레스테롤
(TC), HDL-, LDL 콜레스테롤 및 중성지방 (TG)의 수치를 나타 낸 것이다. $\mathrm{HDL}$-콜레스테롤을 제외한 전 항목에서 대조구 보다 처리구에서 유의적으로 낮은 수치를 보이고 있다 $(\mathrm{p}<0.05)$. 다만 $\mathrm{HDL}$-콜레스테롤의 경우 $\mathrm{T} 1$ 에서만 낮은 수치를 보였으나, T2, T3 와 같이 키토산의 증량에 따라 상승하는 경향을 보이고 있다. 강과 이(2008)는 유사나트륨만 첨가된 처리구에서 고밀도의 좋은 콜레 스테롤로 알려지고 있는 $\mathrm{HDL}$-콜레스테롤도 현저히 감소되어, 이의 약점을 보완할 수 있는 연구의 필요성을 강조한 바 있다. 따라서 $\mathrm{T} 1$ 의 HDL-콜레스테롤의 감소는 유산나트륨의 함량과 관련이 있는 것으로 분석되며, $\mathrm{T} 2, \mathrm{~T} 3$ 에서 처럼 키토산의 함량 조절로써 총콜 레스테롤, LDL-콜레스테롤, 중성지방은 유의적으로 감소시키되, $\mathrm{HDL}$-콜레스테롤은 효과적으로 유지될 수 있다고 사료된다. Sugano 등 (1980)도 쥐의 실험에서 키토산의 섭취결과 혈액 및 간 장 중의 콜레스테롤이 현저히 감소하였으며, Maezaki 등 (1993) 또한 사람을 대상으로 1 일 $0.5 \sim 3 \mathrm{~g}$ 의 키토산을 섭취시킨 결과 혈중 총콜레스테롤은 유의적으로 감소하였으며 $\mathrm{HDL}$-콜레스테롤은 오히 려 상승하였고, 섭취를 중지하면 원래의 상태로 되돌아가는 경향을 보였다고 하였다.

Table 6. Effect of feeding nitrite-reduced sausages added chitosan and sodium lactate on body weight gain (BWG) of rat

\begin{tabular}{lccccc}
\hline \multirow{2}{*}{ Parameters } & \multicolumn{5}{c}{ Treatments } \\
\cline { 2 - 6 } & $\mathrm{C}^{1)}$ & $\mathrm{T}^{2)}$ & $\mathrm{T}^{3)}$ & $\mathrm{T}^{4)}$ & $\mathrm{SEM}^{5)}$ \\
\hline \hline BWG(g) & $56.67^{\mathrm{b}}$ & $81.33^{\mathrm{a}}$ & $75.67^{\mathrm{a}}$ & $75.50^{\mathrm{a}}$ & 5.43 \\
\hline
\end{tabular}

1)-4) Abbreviation is the same as Table 1.

5) Pooled standard error of mean.

${ }^{\mathrm{a}-\mathrm{b}}$ Means with same row having same superscript are not significantly different $(\mathrm{p}<0.05)$.

Table 7. Effect of feeding nitrite-reduced sausages added chitosan and sodium lactate on blood glucose of rat

\begin{tabular}{lccccc}
\hline \multirow{2}{*}{ Parameters (mg/dL) } & \multicolumn{3}{c}{ Treatments } & $\mathrm{T}^{4)}$ & $\mathrm{SEM}^{5}$ \\
\cline { 2 - 6 } & $\mathrm{C}^{1)}$ & $\mathrm{T}^{2)}$ & $\mathrm{T} 2^{3)}$ & $83.17^{\mathrm{a}}$ & 7.75 \\
Pre-Feeding & $91.17^{\mathrm{a}}$ & $106.00^{\mathrm{a}}$ & $93.33^{\mathrm{a}}$ & $155.83^{\mathrm{ab}}$ & 11.63 \\
Post-Feeding & $139.67^{\mathrm{b}}$ & $181.33^{\mathrm{a}}$ & $151.67^{\mathrm{ab}}$ & 15 \\
\hline
\end{tabular}

\footnotetext{
1)-4) Abbreviation is the same as Table 1.

5) Pooled standard error of mean.

${ }^{a-b}$ Means with same row having same superscript are not significantly different $(\mathrm{p}<0.05)$.
} 
Table 8. Effect of feeding nitrite and nitrite-reduced sausages added chitosan and sodium lactate on total cholesterol (TC), HDL, and LDL- cholesterol and triglyceride (TG) concentration of plasma in rat

\begin{tabular}{lccccc}
\hline \multirow{2}{*}{ Parameters $(\mathrm{mg} / \mathrm{dL})$} & \multicolumn{5}{c}{ Treatments } \\
\cline { 2 - 6 } & $\mathrm{C}^{\mathrm{l}}$ & \multicolumn{1}{c}{$\mathrm{T}^{2)}$} & $\mathrm{T} 2^{3)}$ & $\mathrm{T}^{4)}$ & $\mathrm{SEM}^{5)}$ \\
\hline \hline $\left.\mathrm{TC}^{6}\right)$ & $97.00^{\mathrm{a}}$ & $74.50^{\mathrm{b}}$ & $79.50^{\mathrm{b}}$ & $80.67^{\mathrm{b}}$ & 2.63 \\
H.D.L & $29.50^{\mathrm{a}}$ & $25.33^{\mathrm{b}}$ & $28.17^{\mathrm{ab}}$ & $29.83^{\mathrm{a}}$ & 1.08 \\
L.D.L & $17.68^{\mathrm{a}}$ & $9.17^{\mathrm{b}}$ & $11.50^{\mathrm{b}}$ & $11.17^{\mathrm{b}}$ & 1.04 \\
$\mathrm{TG}^{7)}$ & $146.50^{\mathrm{a}}$ & $71.67^{\mathrm{b}}$ & $51.83^{\mathrm{b}}$ & $73.33^{\mathrm{b}}$ & 8.02 \\
\hline
\end{tabular}

1)-4) Abbreviation is the same as Table 1.

5) Pooled standard error of mean.

6) Total cholesterol

7) Total triglyceride

${ }^{\mathrm{a}-\mathrm{b}}$ Means with same row having same superscript are not significantly different $(\mathrm{p}<0.05)$.

\section{요 약}

본 연구는 소시지 제조 시에 첨가되는 아질산염의 대체수단으로 서 이용가능성이 대두된 유산나트륨의 과다 사용량을 줄이고자 키 토산을 첨가함으로서 그 기능성이 보완된 저아질산나트륨, 저유산 나트륨의 소시지를 만드는데 있다. 소시지 제조는 대조구 $(\mathrm{C}$, nitrite $100 \mathrm{ppm})$ 와 처리구 $(\mathrm{T} 1$, nitrite $30 \mathrm{ppm}+$ sodium lactate $2 \%+$ chitosan $0.5 \%$; $\mathrm{T} 2$, nitrite $30 \mathrm{ppm}+$ sodium lactate $1 \%+$ chitosan $1 \%$; T3, nitrite $30 \mathrm{ppm}+$ sodium lactate $0 \%+$ chitosan $1.5 \%$ ) 로 하였으며, 혈액성상을 측정하기위해 실험쥐 24 마리가 4주간 사육되었다. 소시지의 색상은 유의적인 차이를 보인 데 반해, 적색도는 대조구에서 황색도는 키토산이 많은 $\mathrm{T} 3$ 에서 높 게 나타났다. $\mathrm{pH}$ 와 보수력에서 대조구, $\mathrm{T} 1$ 및 $\mathrm{T} 2$ 에서는 유의적인 차이가 없었으나 $\mathrm{T} 3$ 에서는 낮은 $\mathrm{pH}$ 와 낮은 보수력을 보였다. 조직 분석에서 탄력성, 응집성, 씹힘성, 부착성에는 대조구와 처리구간에 유의적인 차이가 없었으나, 경도와 검성은 처리구보다 대조구가 낮 은 값을 나타내었다. 관능검사의 외관과 색상은 대조구에서 높은 점수를 받았으나, 조직감과 풍미에서는 낮은 점수를 받았다. 미생 물수는 냉장저장 1 주에서는 대조구및 처리구간에 유의적인 차이가 없었으나, 냉장저장 3 주에서는 대조구에서 가장 적은 수치를 보였 다 $(\mathrm{p}<0.05)$. TBARS 측정에서 항산화 효과는 처리구보다 대조구 에서 유의적인 차이를 보였다. 혈액성상의 경우, 처리구가 쥐의 증 체효과를 보였으며, 중성지방, 총콜레스테롤 및 LDL-콜레스테롤은 유의적으로 감소되는 효과를 보였다 $(\mathrm{p}<0.05)$. 그러나 처리구 중 $\mathrm{T} 1$ 은 대조구에 비해 혈당은 높고, $\mathrm{HDL}$ - 콜레스테롤이 저하되는 문제를 보였다 $(\mathrm{p}<0.05) . \mathrm{T} 2$ 와 $\mathrm{T} 3$ 간의 증체 및 혈액성상에는 유의 적인 차이가 없었다. 따라서 저 아질산나트륨의 소시지를 제조하고 자 유산나트륨과 키토산을 혼합할 경우, 아질산나트륨의 농도에 따 른 육색 및 항산화력의 보완이 필요하나, 이화학성상에서는 $\mathrm{T} 1$ 이, 혈액성상에서는 $\mathrm{T} 2$ 가 바람직한 것으로 나타나, 키토산을 첨가함으 로서 기능이 보완된 저 아질산나트륨 및 저 유산나트륨의 소시지 제조는 가능하다고 사료된다.
본 연구는 2008학년도 단국대학교 대학연구비 지원에 의하여 연 구된 것으로 이에 감사드립니다.

\section{인 용 문 헌}

강종옥, 이강현. 2003. 레드비트 색소 및 키토산 첨가가 저 아질산염 소시 지에 미치는 효과. 한국축산식품학회지. 23: 215-220.

강종옥, 이상길. 2008. 선인장 색소 및 유산나트륨이 저 아질산염 소시지 에 미치는 효과. 한국동물자원과학회지. 50:551- 560.

김기숙, 최성희. 2007. 육제품의 저장 중 아질산이온 잔류량, TBARS 함 량과 육색의 변화. 한국축산식품학회지. 27:299- 307.

김수민, 조영석, 양태민, 이신호, 김대곤, 성삼경. 2000. 오미자 추출물을

이용한 기능성 소시지 개발. 한국축산식품학회지. 20:272-2281.

류미라, 김은영, 정경숙. 2003. 홍국첨가가 소시지의 품질특성에 미치는 영향. 한국식품과학회지. 35:229-234.

윤선경, 박선미, 김연주, 안동현. 2001. 돈육소시지에 첨가한 키토산의 아 질산염대체효과에 관한 연구. 한국식품과학회지. 33:551-559.

양한술, 정진영, 이정일, 윤이란, 주선태, 박구부. 2006. 녹차추출물의 첨가 가 저장 중 유화형 소시지의 품질 특성 및 아질산염 감소에 미치는 영향. 한국축산식품학회지. 26:454-463.

윤선경, 최정수, 박선미, 안동현. 2004. 키토산 첨가 양념돈육의 저장성 및

품질 개선에 관한 연구. 한국동물자원과학회지. 46:1023-1030.

전유진, 이응호, 김세권. 1996. 키틴, 키토산의 생리기능(1). 한국 키틴 키 토산 연구회지. 1:4-13.

진구복, 최순희. 2001. 젖산나트륨과 지방대체제의 첨가가 냉장저장 중 저 지방 볼로나 소시지의 품질 및 저장성에 미치는 영향. 한국식품영양과 학회지. 30:858-864.

진구복, 김경훈, 이홍철. 2006. 국내 시판 육제품의 이화학적, 조직적 특성

및 미생물의 성상. 한국축산식품학회지. 26:98- 105.

최성희, 권혁추, 안덕준, 박정로, 오동환. 2003. 녹차분말 첨가소시지의 아 
질산염 잔유량과 저장성. 한국축산식품학회지. 23:299-308.

Campbell, Mary K. and Farrel, Shawn O. 2003. The biochemical role of nitric oxide. Biochemistry Fourth ed. Thomson. pp. 645-651.

Choi, S. H. and Chin, K. B. 2009. Product characteristics and shelf-life effect of low fat functional sausages manufactured with sodium lactate and chitosana during storage at $10^{\circ} \mathrm{C}$. Korean J. Food Sci. Ani. Resour. 29:75-85.

Choi, S. H. and Chin, K. B. 2003. Evaluation of sodium lactate as a eplacement for conventional chemical preservatives in comminuted sausages inoculated with Listeria monocytogenes. Meat Sci. 65:531-537.

CODEX Alimentarius Commission. 2007. Codex standard for cooked chopped meat. CODEX STAN 98-191 (rev. 1 1991). In: Official website of Codex Alimentarius Commission, http:// www.codexalimentarius.net.

Judge, M. D., Albert, E. D., Forrest, J. C., Hedrick, H. B. and Merkel, R. A. 1975. Principles of meat science. 2nd Ed., Kendall/Hunt publishing company. pp. 145.

Maezaki, Y., Tsuji, K., Nakagawa, W., Terada, Y., Akimoto, M., Tsugita, T., Takekawa, W., Terada, A., Hara, H. and Mitsuoka, T. 1993. Hypocholesterolemic effect of chitosan in adult males. Biosci. Biotech. Biochem. 57:1439-1444.

Mass, M. R., Glass, K. A. and Doyle, M. P. 1989. Sodium lactate delays toxin production by Clostridium botulinum in ccook-inbag turkey products. Appl. Environ. Microbiol. 55: 2226-2229.

O'Boyle, A., Rubin, L. J., Diosady, L. L., Aladin-Kassam, N., Comer, F. and Brightwell, W. 1990. A nitrite-free meat curing system and its application to the production of wieners. Food Technol. 44:88-104.

Pearson, A. M. and Gillett, T. A. 1996. Processed meats 3rd Ed., Chapman \& Hall. p 57.

Sagoo, S., Board, R. and Roller, S. 2002 Chitosan inhibits growth of spoilage microorganisms in chilled pork products. Food Microbiol. 19:175-182.

SAS. 1999. SAS/STAT Software for PC. Release 6.11. SAS Institute Inc., Cary, NC. USA.

Sugano, M., Fujikawa, T., Hiratsuji, Y., Nakashima, K., Fukuda, N. and Hasegawa, Y. 1980. A novel use of chitosan as a hypocholesterolemia agent in rat. Am. J. Clin., Nutr. 33:787793.

Yang, A., Larsen, T. W., Powell, V. H. and Tume, R. K. 1999. A comparison of fat composition of Japanese and long- term gained fat Australian steers. Meat Sci. 51:1-9.

森田重廣. 1982. 畜肉与 加工. 建帛社. pp. 117 .

(접수일자 : 2009. 10. 15 / 수정일자 : 2009. 12. 17 / 채택일자 : 2010. 1. 13) 